\title{
Genetic Parameters Estimates for Milk Yield, Milk Quality and Mozzarella Production of Romanian Buffalo
}

\author{
Răzvan POPA*1), Dana POPA ${ }^{1)}$, Livia VIDU ${ }^{1)}$, Cristiana DIACONESCU ${ }^{1)}$, Vasile BĂCILĂ $\breve{A}^{1)}$, Adrian BOTA ${ }^{2)}$, \\ Dorel DRONCA ${ }^{3)}$ \\ 1) Faculty of Animal Science, University of Agronomic Science and Veterinary Medicine of Bucharest, 59 \\ Mărăsti Avenue, Romania \\ 2) The Research and Development Station for Buffalo Breeding, Sercaia, Brasov County, Romania \\ ${ }^{3)}$ Faculty of Animal Science and Biotechnologies, University of Agricultural Sciences and Veterinary \\ Medicine of Timisoara, 119 Aradului Avenue, Romania \\ *Corresponding author, email: poparasvan@yahoo.co.uk
}

Bulletin UASVM Animal Science and Biotechnologies 71(2) / 2014,

Print ISSN 1843-5262; Electronic ISSN 1843-536X

DOI:10.15835/buasvmcn-asb:10489

\begin{abstract}
Genetic parameters for milk yield, fat and protein milk content and "mozzarella" index were estimated in the population of Romanian Buffalo from Sercaia Research and Development Station. A total 609 milk yield and associated characters records, belonging to 87 females, which coming from 11 sire families, for 7 lactations were analyzed. The method used for genetic parameters estimates was REML. There was a large variability in all analyzed traits. Estimated heritability was small to medium for al examined traits. The milk yield is negatively correlated with fat and protein content, and weak positive with "mozzarella" index. Fat and protein milk content are high positive correlated with mozzarella production. In the long term, the female selection for milk yield will be (make) to the detriment of quality. Genetic improvement of the quantity of mozzarella will be make only on account of milk constituents that impart its quality. According to heritability values, in the process of female genetic evaluation appears advisable to use additional information sources in order to increase the accuracy of selection.
\end{abstract}

Keywords: buffalo, genetic parameters, milk yield, milk quality, mozzarella production

\section{INTRODUCTION}

In Romania, the buffalo entered with the invasion of the Huns and Avars in the CarpathoDanubian area. It found the good pedo-climatic conditions and so, in our country, has developed a buffalo population which had its own evolutionary path as a result of reproductive isolation (Vidu et al., 2008). The Romanian Buffalo is one of the most important genetic resources for milk and meat production.

Worldwide, in countries where milk production is ensured by buffalo milk, the population of buffalo increased numerical because of the demographical growth of the human population. In Europe, the main country that exploiting buffal is Italy, the main production being mozzarella type soft cheese. In 2004, Romania ranked 2 in Europe in terms of breeding buffalo, with 100,000 heads (Vidu et al., 2008). Consequence of the lack of supportive policies in the area of buffalo, herd showed a decreasing trend in Romania, FAO estimating that there are 70,000 heads in 2006 and Vidu (2007) estimated a population of about 64,000 heads. Compared with cows, buffalo milk has quality parameters with higher values. The fat percentage range between 6.87 to $8.59 \%$ (Rosati and Van Vleck, 2002; Tonhati et al., 2000), protein percentage between 4.13 to $4.55 \%$ (Macedo et al., 2001; Rosati and Van Vleck, 2002). In Romania, Velea and Mărginean (2004) specifies that buffalo's 
milk production falls into the following parameters: average milk yield $1111.11 \mathrm{~kg} /$ lactation, average fat yield $82.10 \mathrm{~kg}(7.39 \%)$, and average protein yield $46.21 \mathrm{~kg}(4.23 \%)$.

Enormous advantage of exploitation of this species for characters associated with milk production, compared with cows and sheep, is the lower cholesterol content of milk and Mozzarella cheese type, despite higher values of the constituents (Zicarelli, 2004). In this respect, it is very important to develop efficient breeding programs to improve population for characters associated with these productions.

As is known, one of the major steps in the design of the breeding program is to determine with maximum accuracy the population genetic structure. Many of the decisions to be taken in animal breeding, in relation to the choice of breeding system and selection methods, depend on the values of genetic parameters. The accuracy of the genetic parameter estimation depends on the amount and quality of the primary data and the statistical model selection (Grosu et al., 2005; Popa, 2009).

There are a number of studies showing estimates of genetic parameter values related to buffalo milk yield (Aspilcueta-Borquis et al., 2010; Farhangfar et al., 2005; Rosati and Van Vlek, 2002; Sarubbi et al., 2012; Seno et al., 2006; Tonhati et al., 2000) and milk quality parameters (AspilcuetaBorquis et al., 2010; Rosati and Van Vlek, 2002; Seno et al., 2006; Tonhati et al., 2000).

Concern for the production of mozzarella is underlined in several studies, fewer in number, dealing with issues of estimating genetic parameters for this trait and the relationship between the mozzarella yield and buffalo milk quality components (Aspilcueta- Borquis et al., 2010; Rosati and Van Vlek, 2002; Sarubbi et al., 2012).

The objective of this study was to estimate genetic parameters for milk yield, fat and protein milk content and "mozzarella" index, using a methodology that gives the maximum accuracy in conditions of the existence an inconsistent data.

\section{MATERIALS AND METHODS}

In order to estimate genetic parameter values, were used the data resulting following control milk production in females belonging Şercaia Research and Development Station. To analyze parameters in dynamic were included in the analysis only animals presenting records to an equal number of lactations.

A total 609 milk yield and associated characters records, belonging to 87 females, which coming from 11 sire families, for 7 lactations were analyzed.

The traits studied were: milk yield per lactation, milk fat and protein content, and "mozzarella" index.

In control milk production, records with length greater than 270 days were truncated at this point, as suggested by Tonhati et al. (2008) and Aspilcueta-Borquis et al. (2010).

The amount of Mozzarella was estimated using the relationship proposed by Altiero et al (1989) and used in the national genetic evaluation in Italy:

\section{$\mathrm{MP}(\mathrm{kg})=\mathrm{MY} *\{[(3.5 * \% \mathrm{P})+(1.23 * \% \mathrm{~F})-0.88] / 100\}$}

in which:

MP = Mozzarella yield (accumulated at 270 days)

$\mathrm{MY}=$ milk yield

$\% \mathrm{P}=$ protein percent

$\% \mathrm{~F}=$ fat percent

For data characterization, the classical statistical method were used: average $\left(\bar{X} \pm s_{\bar{X}}\right)$, standard deviation (s) and variability coefficient (CV\%)(Sandu, 1995). The method used for genetic parameters estimates was REML developed by Sir Ronald Fisher (1925) and perfected by Patterson and Thompson (1971).

\section{RESULTS AND DISCUSSION}

The first step in developing breeding programs is to establish the population status. Any strategy to population genetic improvement requires knowledge of the existing situation on the mean and variability of characters that can be selection objective.

The results on the average performance of milk production traits are presented in Tab. 1, Tab. 2, Tab. 3 and Tab 4.

The data presented in Tables 1-4 shows that the average values associated with milk production traits are characteristic of a buffaloe population. The values obtained are similar to those reported by Tonhati et al. (2000) and Sarubbi et al. (2012), but lower than those obtained Malhado et al. (2007). 
The variability is highest for all the examined traits, most likely due to human error associated with the measurement, without neglecting individual variation caused by various factors (genetic and environmental). The values of the descriptive statistics indicate the existence of a population that can constitute object of a breeding program, with a sufficiently large field for action of artificial selection.

Heritability is defined as the rate of additive genetic variance in the phenotypic variance. Since the breeding program can act only on additive genetic variation within population (the breeding value is only component of phenotypic value that is transmitted in descent), other components of genetic variation is limited by raw material and the particular environment in which experiment takes place, estimates of heritability coefficients are considered very important as indicators of effectiveness of these programs. Heritability coefficient values for the traits studied in dynamics are presented in Tab. 5 .

The analysis of data presented in Tab. 5 shows that the milk yield is a character that has

Tab. 1. Descriptive statistics for milk yield

\begin{tabular}{lccccc}
\hline \multirow{2}{*}{ Specification } & U.M. & $\mathrm{n}$ & $\bar{X} \pm s_{\bar{X}}$ & $\mathrm{~s}$ & \multirow{2}{*}{ CV\% } \\
\hline Lactation 1 & $\mathrm{kg}$ & 87 & $942.32 \pm 41.01$ & 382.53 & 40.59 \\
\hline Lactation 2 & $\mathrm{kg}$ & 87 & $1038.21 \pm 44.50$ & 415.05 & 39.98 \\
\hline Lactation 3 & $\mathrm{kg}$ & 87 & $1181.47 \pm 49.72$ & 463.79 & 39.25 \\
\hline Lactation 4 & $\mathrm{kg}$ & 87 & $1274.73 \pm 47.58$ & 443.78 & 34.81 \\
\hline Lactation 5 & $\mathrm{kg}$ & 87 & $1371.47 \pm 51.31$ & 478.59 & 34.90 \\
\hline Lactation 6 & $\mathrm{kg}$ & 87 & $1479.17 \pm 55.46$ & 517.31 & 34.97 \\
\hline Lactation 7 & $\mathrm{kg}$ & 87 & $1421.32 \pm 50.51$ & 471.14 & 33.15 \\
\hline
\end{tabular}

Tab. 2. Descriptive statistics for fat yield

\begin{tabular}{lccccc}
\hline Specification & U.M. & $\mathrm{n}$ & $\bar{X} \pm s_{\bar{X}}$ & $\mathrm{~s}$ & $\mathrm{CV} \%$ \\
\hline Lactation 1 & $\mathrm{kg}$ & 87 & $65.03 \pm 2.84$ & 26.48 & 40.72 \\
\hline Lactation 2 & $\mathrm{kg}$ & 87 & $74.03 \pm 3.61$ & 33.63 & 45.42 \\
\hline Lactation 3 & $\mathrm{kg}$ & 87 & $81.53 \pm 3.79$ & 35.35 & 43.36 \\
\hline Lactation 4 & $\mathrm{kg}$ & 87 & $88.04 \pm 3.92$ & 36.57 & 41.54 \\
\hline Lactation 5 & $\mathrm{kg}$ & 87 & $94.58 \pm 4.02$ & 37.49 & 39.64 \\
\hline Lactation 6 & $\mathrm{kg}$ & 87 & $101.93 \pm 4.13$ & 38.54 & 37.81 \\
\hline Lactation 7 & $\mathrm{kg}$ & 87 & $99.07 \pm 3.82$ & 35.59 & 35.93 \\
\hline
\end{tabular}

Tab. 3. Descriptive statistics for protein yield

\begin{tabular}{lccccc}
\hline \multirow{2}{*}{ Specification } & U.M. & $\mathrm{n}$ & $\bar{X} \pm s_{\bar{X}}$ & $\mathrm{~s}$ & CV\% \\
\hline Lactation 1 & $\mathrm{kg}$ & 87 & $40.40 \pm 1.83$ & 17.08 & 42.28 \\
\hline Lactation 2 & $\mathrm{kg}$ & 87 & $43.18 \pm 1.88$ & 17.56 & 40.67 \\
\hline Lactation 3 & $\mathrm{kg}$ & 87 & $53.40 \pm 2.31$ & 21.59 & 40.43 \\
\hline Lactation 4 & $\mathrm{kg}$ & 87 & $53.00 \pm 1.98$ & 18.49 & 34.89 \\
\hline Lactation 5 & $\mathrm{kg}$ & 87 & $61.13 \pm 2.31$ & 21.54 & 35.23 \\
\hline Lactation 6 & $\mathrm{kg}$ & 87 & $61.48 \pm 2.34$ & 21.80 & 35.46 \\
\hline Lactation 7 & $\mathrm{kg}$ & 87 & $61.13 \pm 2.84$ & 20.88 & 34.15 \\
\hline
\end{tabular}

Tab. 4. Descriptive statistics for mozzarella yield

\begin{tabular}{lccccc}
\hline \multirow{2}{*}{ Specification } & U.M. & $\mathrm{n}$ & $\bar{X} \pm s_{\bar{X}}$ & $\mathrm{~s}$ & CV\% \\
\hline Lactation 1 & $\mathrm{kg}$ & 87 & $213.11 \pm 9.22$ & 85.97 & 40.34 \\
\hline Lactation 2 & $\mathrm{kg}$ & 87 & $233.04 \pm 10.41$ & 97.13 & 41.68 \\
\hline Lactation 3 & $\mathrm{kg}$ & 87 & $276.78 \pm 12.12$ & 113.08 & 40.86 \\
\hline Lactation 4 & $\mathrm{kg}$ & 87 & $282.57 \pm 11.16$ & 104.06 & 36.83 \\
\hline Lactation 5 & $\mathrm{kg}$ & 87 & $318.21 \pm 12.44$ & 116.04 & 36.46 \\
\hline Lactation 6 & $\mathrm{kg}$ & 87 & $327.53 \pm 12.65$ & 117.96 & 36.01 \\
\hline Lactation 7 & $\mathrm{kg}$ & 87 & $323.30 \pm 11.85$ & 110.48 & 34.17 \\
\hline
\end{tabular}


Tab. 5. Heritability values for the analyzed traits

\begin{tabular}{lccccccc}
\hline \multirow{2}{*}{ Specification } & Lactation & Lactation & Lactation & Lactation & Lactation & Lactation & Lactation \\
& 1 & 2 & 3 & 4 & 5 & 6 & 7 \\
\cline { 2 - 8 } & $h^{2} \pm S_{h^{2}}$ & $h^{2} \pm S_{h^{2}}$ & $h^{2} \pm S_{h^{2}}$ & $h^{2} \pm S_{h^{2}}$ & $h^{2} \pm S_{h^{2}}$ & $h^{2} \pm S_{h^{2}}$ & $h^{2} \pm S_{h^{2}}$ \\
\hline Milk yield & $0.12 \pm 0.27$ & $0.07 \pm 0.25$ & $0.08 \pm 0.25$ & $0.52 \pm 0.44$ & $0.14 \pm 0.28$ & $0.18 \pm 0.29$ & $0.32 \pm 0.35$ \\
\hline Fat yield & $0.14 \pm 0.28$ & $0.11 \pm 0.26$ & $0.14 \pm 0.28$ & $0.51 \pm 0.43$ & $0.24 \pm 0.32$ & $0.22 \pm 0.31$ & $0.25 \pm 0.32$ \\
\hline Protein yield & $0.14 \pm 0.28$ & $0.08 \pm 0.25$ & $0.11 \pm 0.26$ & $0.52 \pm 0.44$ & $0.19 \pm 0.30$ & $0.20 \pm 0.30$ & $0.34 \pm 0.36$ \\
\hline $\begin{array}{l}\text { Mozzarella } \\
\text { yield }\end{array}$ & $0.14 \pm 0.28$ & $0.08 \pm 0.25$ & $0.10 \pm 0.26$ & $0.53 \pm 0.44$ & $0.18 \pm 0.29$ & $0.20 \pm 0.30$ & $0.36 \pm 0.37$ \\
\hline
\end{tabular}

a low to medium genetic determinism, along the 7 lactations analyzed. The variation of heritability coefficient from one age to another can be explained by the existence of different polygenic complex that is involved in genetic determining of milk yield, environmental conditions influence and human error associated with control process.

For milk yield, selection of females based on own performances seems to be a method which can't ensure that in descent, the phenotypic manifestation of the character is found at a value close to that of their parents. Thus, at least for the current status of the population, there is recommended to use additional sources in genetic evaluation of buffaloes (average performance of mother and halfsibs) to increase the accuracy of selection.

Heritability coefficient values for milk yield that we found are similar to those reported by other authors (Farhangfar et al., 2005; Rosati and Van Vlek, 2002; Sarubbi et al., 2012; Seno et al., 2006; Tonhati et al., 2000).

Regarding the characters that are related to milk quality (fat yield, protein yield and Mozzarella index), the results presented in Tab. 5 shows that they can be placed in group of low to intermediate heritable traits. As in the case of milk yield, buffaloes' selection can not be made using only their own performance.

Heritability coefficient values for milk quality that we found are similar to those reported by other authors (Rosati and Van Vlek, 2002; Sarubbi et al., 2012; Seno et al., 2006; Tonhati et al., 2000), but in contradiction to those reported by Velea (1992).

We mention that the small values of heritability characters and the differences between age can be attributed either to errors due to sample size, or poor control of milk production (in the sense of inaccurate records), or both. Thus, it becomes imperative to improve the conditions of control, raising accuracy.
The efficiency of genetic gain depends, in addition to heritability, on the number of considered traits and the interdependence between them. Of all the correlations, the genetic interests more, because according to its value the characters are included in selection objective.

To track the existence of a common gene pool in polygenic complexes that determining traits were determined phenotypical, genotypical and environmental correlations, whose values are presented in Tab. 6, Tab. 7, Tab. 8, Tab. 9, Tab. 10, Tab. 11 and Tab. 12.

The results presented in Tables 6-12 show the existence of positive environmental correlations for all couple of characters related to milk quality, with different degrees of intensity (with one exception, interdependence is close). Thus, environmental conditions affect the evolution of these couple of characters in the same direction. In other words, the environment is very important in ensuring the quality of milk, obtaining a large amount of Mozzarella cheese being directly dependent on strict compliance with the requirements, especially nutrition. The milk yield is negative correlated with fat and protein yield, which means that long-term selection of females for quantity of milk is made in detriment of its quality. A very weak positive interdependence is

Tab. 6. Phenotypical $\left(\mathrm{r}_{\mathrm{F}}\right)$, genotypical $\left(\mathrm{r}_{\mathrm{G}}\right)$ and environmental $\left(\mathrm{r}_{\mathrm{E}}\right)$ correlation estimates for lactation 1

\begin{tabular}{cccc}
\hline Couple of traits & $\mathrm{r}_{\mathrm{F}}$ & $\mathrm{r}_{\mathrm{G}}$ & $\mathrm{r}_{\mathrm{E}}$ \\
\hline Milk yield $\mathrm{x}$ & & & \\
- fat yield & $-0,16$ & $-0,15$ & $-0,17$ \\
- protein yield & $-0,24$ & $-0,21$ & $-0,25$ \\
- Mozzarella yield & 0,02 & 0,03 & 0,02 \\
\hline Fat yield x & & & \\
- protein yield & 0,24 & 0,25 & 0,24 \\
- Mozzarella yield & 0,95 & 0,88 & 0,96 \\
\hline Protein yield $\mathrm{x}$ & & & \\
- Mozzarella yield & 0,92 & 0,92 & 0,91 \\
\hline
\end{tabular}


found between milk yield and Mozzarella index, which points out that, in the study population, although milk production is the main component of the formula for determining the index, its improvement will be made only on behalf of milk constituents, which gives it quality. This fact is also sustained by very strong positive correlation between the Mozzarella index and fat and protein yield, along all analyzed lactations. The results contradict those presented by Rosati and Van Vlek (2002), De Paula et al. (2008), Sarubbi et al. (2012).

Tab. 7. Phenotypical $\left(r_{F}\right)$, genotypical $\left(r_{G}\right)$ and environmental $\left(\mathrm{r}_{\mathrm{E}}\right)$ correlation estimates for lactation 2

\begin{tabular}{cccc}
\hline Couple of traits & $\mathrm{r}_{\mathrm{F}}$ & $\mathrm{r}_{G}$ & $\mathrm{r}_{\mathrm{F}}$ \\
\hline Milk yield $\mathrm{x}$ & & & \\
- fat yield & $-0,13$ & $-0,10$ & $-0,14$ \\
- protein yield & $-0,25$ & $-0,25$ & $-0,25$ \\
- Mozzarella yield & 0,03 & 0,04 & 0,03 \\
\hline Fat yield x & & & \\
- protein yield & 0,19 & 0,13 & 0,18 \\
- Mozzarella yield & 0,97 & 0,73 & 0,99 \\
\hline Protein yield $\mathrm{x}$ & & & \\
- Mozzarella yield & 0,90 & 0,89 & 0,90 \\
\hline
\end{tabular}

Tab. 8. Phenotypical $\left(\mathrm{r}_{\mathrm{F}}\right)$, genotypical $\left(\mathrm{r}_{\mathrm{G}}\right)$ and environmental $\left(r_{E}\right)$ correlation estimates for lactation 3

\begin{tabular}{cccc}
\hline Couple of traits & $\mathrm{r}_{\mathrm{F}}$ & $\mathrm{r}_{\mathrm{G}}$ & $\mathrm{r}_{\mathrm{E}}$ \\
\hline Milk yield $\mathrm{x}$ & & & \\
- fat yield & $-0,15$ & $-0,09$ & $-0,15$ \\
- protein yield & $-0,24$ & $-0,23$ & $-0,23$ \\
- Mozzarella yield & 0,04 & 0,05 & 0,03 \\
\hline Fat yield x & & & \\
- protein yield & 0,23 & 0,15 & 0,24 \\
- Mozzarella yield & 0,97 & 0,94 & 0,98 \\
\hline Protein yield x & & & \\
- Mozzarella yield & 0,91 & 0,89 & 0,90 \\
\hline
\end{tabular}

Tab. 9. Phenotypical $\left(\mathrm{r}_{\mathrm{F}}\right)$, genotypical $\left(\mathrm{r}_{\mathrm{G}}\right)$ and environmental $\left(\mathrm{r}_{\mathrm{E}}\right)$ correlation estimates for lactation 4

\begin{tabular}{cccc}
\hline Couple of traits & $\mathrm{r}_{\mathrm{F}}$ & $\mathrm{r}_{\mathrm{G}}$ & $\mathrm{r}_{\mathrm{E}}$ \\
\hline Milk yield $\mathrm{x}$ & & & \\
- fat yield & $-0,13$ & $-0,12$ & $-0,12$ \\
- protein yield & $-0,27$ & $-0,25$ & $-0,26$ \\
- Mozzarella yield & 0,04 & 0,03 & 0,03 \\
\hline Fat yield x & & & \\
- protein yield & 0,18 & 0,19 & 0,17 \\
- Mozzarella yield & 0,98 & 0,99 & 0,97 \\
\hline Protein yield $\mathrm{x}$ & & & \\
- Mozzarella yield & 0,90 & 0,90 & 0,89 \\
\hline
\end{tabular}

\section{CONCLUSION}

Milk yield, milk quality components and Mozzarella yield in Romanian buffalo population have enough genetic variation for selection. In the log term, the female selection for milk yield will be make to the detriment of quality. Genetic improvement of the quantity of mozzarella will be made only on account of milk constituents that impart its quality. According to heritability values, in the process of female genetic evaluation appears advisable to use additional information sources in order to increase the accuracy of selection.

Tab. 10. Phenotypical $\left(r_{F}\right)$, genotypical $\left(r_{G}\right)$ and environmental $\left(r_{E}\right)$ correlation estimates for lactation 5

\begin{tabular}{cccc}
\hline Couple of traits & $\mathrm{r}_{\mathrm{F}}$ & $\mathrm{r}_{\mathrm{G}}$ & $\mathrm{r}_{\mathrm{F}}$ \\
\hline Milk yield $\mathrm{x}$ & & & \\
- fat yield & $-0,14$ & $-0,09$ & $-0,15$ \\
- protein yield & $-0,24$ & $-0,23$ & $-0,24$ \\
- Mozzarella yield & 0,04 & 0,05 & 0,03 \\
\hline Fat yield x & & & \\
- protein yield & 0,22 & 0,15 & 0,23 \\
- Mozzarella yield & 0,98 & 0,99 & 0,97 \\
\hline Protein yield x & & & \\
- Mozzarella yield & 0,91 & 0,89 & 0,91 \\
\hline
\end{tabular}

Tab. 11. Phenotypical $\left(\mathrm{r}_{\mathrm{F}}\right)$, genotypical $\left(\mathrm{r}_{\mathrm{G}}\right)$ and environmental $\left(r_{E}\right)$ correlation estimates for lactation 6

\begin{tabular}{cccc}
\hline Couple of traits & $\mathrm{r}_{\mathrm{F}}$ & $\mathrm{r}_{G}$ & $\mathrm{r}_{\mathrm{F}}$ \\
\hline Milk yield x & & & \\
- fat yield & $-0,15$ & $-0,13$ & $-0,16$ \\
- protein yield & $-0,25$ & $-0,24$ & $-0,25$ \\
- Mozzarella yield & 0,03 & 0,03 & 0,02 \\
\hline Fat yield x & & & \\
- protein yield & 0,21 & 0,19 & 0,22 \\
- Mozzarella yield & 0,98 & 0,99 & 0,98 \\
\hline Protein yield x & & & \\
- Mozzarella yield & 0,91 & 0,90 & 0,92 \\
\hline
\end{tabular}

Tab. 12. Phenotypical $\left(\mathrm{r}_{\mathrm{F}}\right)$, genotypical $\left(\mathrm{r}_{\mathrm{G}}\right)$ and environmental $\left(\mathrm{r}_{\mathrm{E}}\right)$ correlation estimates for lactation 7

\begin{tabular}{cccc}
\hline Couple of traits & $\mathrm{r}_{\mathrm{F}}$ & $\mathrm{r}_{\mathrm{G}}$ & $\mathrm{r}_{\mathrm{F}}$ \\
\hline Milk yield $\mathrm{x}$ & & & \\
- fat yield & $-0,15$ & $-0,17$ & $-0,14$ \\
- protein yield & $-0,24$ & $-0,20$ & $-0,26$ \\
- Mozzarella yield & 0,03 & 0,04 & 0,03 \\
\hline Fat yield x & & & \\
- protein yield & 0,22 & 0,36 & 0,19 \\
- Mozzarella yield & 0,97 & 0,98 & 0,97 \\
\hline Protein yield $\mathrm{x}$ & & & \\
- Mozzarella yield & 0,91 & 0,94 & 0,90 \\
\hline
\end{tabular}




\section{REFERENCES}

1. Altiero V, Moio L and Addeo F (1989). Previsione della resa in "mozzarella" sulla base del contenuto in graso e proteine del latte di bufala. Sci. Tec. Lattiero-Casearia 40: 425-433.

2. Aspilcueta-Borquis R et al. (2010). Genetic parameter estimates for buffalo milk yield, milk quality and mozzarella production and Bayesian inference analysis of their relationships. Genet. Mol. Res. 9 (3): 1636-1644.

3. De Paula MC et al (2008). Estimates of genetic. Braz J Anim Sci., 37: 824-8.

4. Farhangfar H et al (2003). Estimation of heritability, repeatability and genetic trend for milk yield of Iranian buffalo in Khuzestan province of Iran using a univariate repeatability animal model, Journal of Animal Sci., vol. 85: 6 3-68.

5. Grosu H et al (2005). Programe de ameliorare genetică în zootehnie. Ed. Ceres, București.

6. Macedo MP, Wechsler FS, Ramos AA, Amaral JB et al. (2001). Composição físico-química e produção do leite de búfalas da raça Mediterrâneo no oeste do Estado de São Paulo. Rev. Bras. Zoot. (Suppl 1) 30: 1084-1088.

7. Malhado $\mathrm{CH}$ et al (2007). Parâmetros e tendências. Rev Brasil de Zoot 2007; 37: 376-79.

8. Patterson H, Thompson R (1971). Recovery of interblock information when block size are unequal. Biometrica 58: 545.

9. Popa R. (2009). Programe de ameliorare. Ed. Printech, București.

10. Rosati A, Van Vleck LD (2002). Estimation of genetic parameters for milk, fat, protein and Mozzarella cheese production for the Italian River buffalo Bubalis bubalis population. Livest. Prod. Sci. 74: 185-190.

11. Sandu Gh (1995). Modele experimentale în zootehnie. Ed. Coral Sanivet, București.

12. Sarrubi F et al. (2012). Milk Yield and Quality to Estimate Genetic Parameters in Buffalo Cows. Journal of Buffalo Sci., 1, 102-106.

13. Seno L et al. (2006). Responses to selection for milk traits in dairy buffaloes. Genet. Mol. Res. 5 (4): 790-796.

14. Tonhati $\mathrm{H}$ et al. (2000). Genetic aspects of productive and reproductive traits in a Murrah buffalo herd in Sao Paulo, Brazil. Journal of Animal Breeding and Genetics, 331-336.

15. Tonhati $\mathrm{H}$ et al. (2008). Test-day milk yield as a selection criterion for dairy buffaloes (Bubalus bubalis Artiodactyla, Bovidae). Genet. Mol. Biol. 31: 674-679.

16. Velea C (1992). Program de ameliorare al rasei Romanească de bubaline, Bulletin UASVM-CN, 219-224.

17. Velea C, Mărgineanu Gh (2004). Producția, reproducţia şi ameliorarea taurinelor. Ed. Tehnică Agricolă Bucureşti.

18. Vidu Livia, Georgescu Gh, Udroiu Alina, Ungureanu Maria, Vlăsceanu Florentina (2007). Studiu asupra parametrilor calitativi ai laptelui de bivoliță la o populație din zona de sud a României. The 36th International Session of Scientific Communications, november 14-16.

19. Vidu Livia, Popa R, Gras M (2008). Stadiul, direcțiile și obiectivele ameliorării bubalinelor din România. Ed. Alpha Mdn, Buzău.

20. Zicarelli L (2004). Buffalo milk: its properties, dairy yield and mozzarella production. Vet. Res. Commun. (Suppl 1) 28: 127-135. 